Acta vet. scand. 1974 ,

From the Department of Clinical Biochemistry, Royal Veterinary College, and the Department of Physiology, Gymnastik- och idrottshögskolan, Stockholm, Sweden.

\title{
FIBRE COMPOSITION, ENZYME ACTIVITY AND CONCENTRATIONS OF METABOLITES AND ELECTROLYTES IN MUSCLES OF STANDARDBRED HORSES*
}

\author{
By \\ Arne Lindholm and Karin Piehl
}

\begin{abstract}
LINDHOLM, ARNE and KARIN PIEHL: Fibre composition, enzyme activity and concentrations of metabolites and electrolytes in muscles of standardbred horses. Acta vet. scand. 1974, 15, 287-309. - Measurements of metabolites, electrolytes, water, RNA and protein concentrations, the activity of certain muscle enzymes (SDH and PFK) and muscle fibre composition were made on biopsy specimens from the gluteus medius muscle of 68 standardbred horses, $1 / 2$ to 8 years old. The muscle fibres were classified in 3 major categories, slow twitch (ST), fast twitch and high oxidative (FTH) and fast twitch (FT) fibres. The percentage of FTH fibres was higher after the age of 4 years, averaging $54 \%$. ST fibres comprised $24 \%$ and this value remained unchanged.

Glycogen concentration increased with age and averaged 95 and $126 \mathrm{mmol} \times \mathrm{kg}^{-1}$ wet muscle in the youngest and oldest age groups, respectively. Lactate and pyruvate concentrations were markedly decreased, whereas ATP, CP, G-6-P and glucose were unaffected with age. Water content averaged $75 \%$ in all age groups, whereas $\mathrm{Na}^{+}$concentration increased, $\mathrm{K}^{+}$concentration decreased and $\mathrm{Mg}^{2+}$ concentration remained unchanged with increasing age. SDH activity in $1 / 2$ - and 8-year old horses increased from 6.1 to $13.6 \mu \mathrm{mol} \times(\mathrm{g} \times \mathrm{min} \text {. })^{-1}$. PFK activity reached a peak at the age of 4 years after which it declined. With the data presented as a background, measurements on muscle biopsies may be a new aid in diagnosing diseases in horses and even in evaluating treatment. Of special interest might be investigations of muscle biopsy specimens as a base in the formation of more adequate training methods in race-horses.
\end{abstract}

electrolytes; fibretypes; glycogenstorage; horse skeletal muscle; phosphofructokinase; succinate deh y drogenase.

* This study was supported by grants from the Swedish Medical Research Council and the Wallenberg Foundation. 
In humans, some muscular disorders are due to derangement of muscle metabolism (McArdle 1951, Müller \& Kugelberg 1959). However, changes in muscle metabolism are also believed to be the cause of muscular disorders in the horse (Carlström 1932). In order to investigate muscular disorders in race-horses, a thorough knowledge is required of normal muscle metabolism and the normal biochemical and histochemical composition of muscles under different training conditions. Since the race-horse is a highly trained athlete, a comparison of horse muscle metabolism with the metabolism of other species, especially man, is a subject of great interest. Thus, the aim of the present investigation was to study the muscle content of different substrates and metabolites in untrained and trained standardbred race-horses at different ages. The study included an investigation of normal values for electrolytes, enzymes and other constituents of skeletal muscle and a histochemical study of muscle fibres.

\section{MATERIAL}

A total of 68 standardbred trotters (26 stallions, 24 mares and 18 geldings) were studied. Their ages ranged from $1 / 2$ to 8 years. The condition and physical ability of the horses varied considerably, depending on the age and maturation of the horses. The training of standardbred horses in Sweden starts at 2 years of age, and most horses make their racing débuts as 3-year olds. In general, horses are trained 6 days a week with maximal or near-maximal speeds employed twice a week.

\section{METHODS AND PROCEDURE}

All samplings were made in the morning after the horses had been fed. The horses were not sedated in connection with sampling. Biopsies were taken mainly from the gluteus medius muscle. This muscle is convenient for biopsies because of its size and the fact that it contains large areas where samples can be taken without injuring vessels or nerves. This muscle is suitable for metabolic studies, as changes in muscle temperatures and lactate concentration relate to work intensities (Lindholm 1973).

\section{Sampling technique}

Biopsies were obtained with a biopsy needle with an external diameter of $5 \mathrm{~mm}$, using a modified version of the technique 
described by Bergström (1962). After careful shaving and disinfection, a small area of the skin and subcutaneous tissue was anaesthetized with $2-3 \mathrm{ml}$ of $2 \%$ Xylocaine (Astra, Sweden) $10 \mathrm{~cm}$ dorso-caudal to the trochanter major of the tuber coxae. A small amount of Xylocaine was also injected beneath the fascia. A $5 \mathrm{~mm}$ skin incision was made with a scalpel. The tightness of the gluteal fascia covering this muscle made it necessary for the incision to include the fascia. Muscle samples weighing 20-40 mg were obtained in 1 puncture by pushing the inner cylinder of the needle back and forth $1-3$ times in the deep part of the muscle belly. As the needle was being withdrawn, 2 fingers were pressed on the skin surface, 1 on either side of the needle, in order to keep the skin in place and keep dust from being drawn into the wound. A local infection might otherwise have developed. Each biopsy sampling only lasted $1-3$ sec. The muscle sample was immediately frozen in liquid nitrogen. As many as 20 repeated biopsies were taken from a single horse on the same day the horse was being trained in rapid intervals. A total of about 2000 biopsies were taken from various horses, and none of the biopsied horses became lame or suffered any side-effects from the biopsy procedure. No gait disturbance or fibrotic scar tissue reaction was observed, even when up to 30 biopsies were taken from the same muscle or 100 biopsies from the same horse. In 1 horse, however, a haematoma developed in the muscle following a biopsy. The haematoma was absorbed and the horse fit again after 5 days.

\section{Histochemical analyses}

For fibre analyses, the muscle specimens were mounted in O.C.T. embedding medium (Ames Tissue-Tek) onto specimen holders and frozen in isopentane cooled in liquid nitrogen. Transverse serial sections were cut in a cryostat at $-20^{\circ} \mathrm{C}$ and mounted on cover glasses for histochemical staining (Gollnick et al. $1972 \mathrm{a})$. The identification of muscle fibres was based on the staining intensity of myofibrillar adenosine triphosphatase (ATPase) (Padykula \& Herman 1955) and reduced nicotinamide adenine dinucleotide diaphorase (NADH-diaphorase) (Novikoff et al. 1961). The myofibrillar ATPase staining reflects the contractile characteristics of muscle fibres (Barnard et al. 1971), and the NADH-diaphorase staining provides an approximation of the oxidative capacity of the fibres (Barnard et al. 1970). On 
this basis, 3 fibre types were identified. They were slow twitch, high oxidative (ST); fast twitch, high oxidative (FTH) and fast twitch, low oxidative (FT) (Table 1). Glycogen distribution was estimated using the periodic acid-Schiff reaction (PAS) (Pearse 1961). The intensity of PAS staining was subjectively rated under the light microscope as dark, moderate, light or negative (Gollnick et al. $1972 \mathrm{~b}$ ). The cross-section of the 3 fibre types was determined by direct planimetry of photographs made of sections stained for NADH-diaphorase.

Table 1. Staining intensity for myofibrillar ATPase, NADH-diaphorase and PAS in the different fibre types.

\begin{tabular}{lccc}
\hline & \multicolumn{3}{c}{ Fibres } \\
\cline { 2 - 4 } & ST & FTH & FT \\
\hline Myofibrillar ATPase (pH 9.4) & - & +++ & +++ \\
NADH-diaphorase & +++ & ++ & $(+)$ \\
PAS & ++ & $++(+)$ & +++ \\
\hline
\end{tabular}

$+++=$ All fibres highly stained; $++(+)=:$ Most fibres highly stained but a few moderately stained; $++=$ All fibres moderately stained; $(+)=$ Most fibres lightly stained; $-=$ No fibres stained.

\section{Total water, electrolytes and protein determinations}

Total water content was determined by weighing frozen muscle specimens on a Cahn Electro-balance at a temperature of $-35^{\circ} \mathrm{C}$ (Karlsson 1971). After $2 \mathrm{hrs}$. in a thermostate at 105 $110^{\circ} \mathrm{C}$ the samples were reweighed on a Cahn Electro-balance at room temperature.

Sodium $\left(\mathrm{Na}^{+}\right)$and potassium $\left(\mathrm{K}^{+}\right)$were analyzed with a flame photometer (Model 143, Instrumentation Lab. Inc., Lexington, Mass., USA). After drying and reweighing the muscle samples were kept overnight in $100 \mu 12 \mathrm{~N}-\mathrm{HNO}_{3}$ (nitric acid). After centrifugation $1 \mathrm{ml}$ of a 15 meq. Li solution was added to $5 \mu \mathrm{l}$ of the supernatant. Magnesium $\left(\mathrm{Mg}^{2+}\right)$ was determined with a Perkin Elmer atomic absorption spectrophotometer (Model 403) using $5 \mu \mathrm{l}$ of the supernatant after adding $1 \mathrm{ml}$ of $0.5 \% \mathrm{La}$ $\left(\mathrm{NO}_{3}\right)_{3}$. Total nitrogen content was determined by using the semi-micro Kjeldal method (Jacobs 1965) with protein content estimated from nitrogen employing a factor of $\mathbf{6 . 2 5}$. 


\section{Biochemical analyses}

Muscle samples obtained for biochemical analyses of metabolites, i.e. glycogen, pyruvate, lactate, adenosine triphosphate (ATP), creatine phosphate (CP), glucose and glucose-6-phosphate (G-6-P) were immediately frozen (within $3-5$ sec.) and stored at $-80^{\circ} \mathrm{C}$ until subsequenly analyzed according to the Lowry method as described by Karlsson et al. (1970). Metabolite concentrations are expressed as wet weight values.

\section{Enzyme activities}

Muscle samples for enzyme assay were carefully inspected and freed from visible connective tissue. The samples were then weighed at different time intervals in order to obtain the wet weight at zero time (Bergström). They were then frozen in liquid nitrogen and always analyzed the same or the next day. The activity of succinic acid dehydrogenase (SDH) and phosphofructokinase (PFK) was determined according to Cooperstein et al. (1950) and Shonk \& Boxer (1964), respectively. Ribonucleic acid (RNA) was determined according to a modified Schmidt-Thannhauser method described by Munro \& Fleck (1966). Yeast RNA was used as the standard.

\section{Variation between muscles and sampling occasions}

Biopsy specimens were obtained from muscles other than the gluteus medius to ascertain whether or not there were any differences in fibre population and enzyme activity in different muscles. The muscles examined were the quadriceps femoris, triceps brachii and infraspinatus.

Variations in glycogen and lactate contents in the gluteus medius on 1 day and during 1 week were also analyzed. Biopsy specimens were taken from 4 horses on 4 occasions on a single day, i.e. at 7 a.m., 10 a.m., 1 p.m. and 4 p.m. The horses were not trained that day but were fed as usual. Six horses trained daily were sampled each day for 1 week. The samples were taken before the start of the daily workout.

\section{Statistical methods}

Conventional statistical methods were used (Bonnier \& Tedin 1957, Snedecor \& Cochran 1967). The levels of significance were denoted: 


$\begin{array}{ll}\text { non-significant } & \quad P>0.05 \\ \text { almost significant } & 0.05>P>0.01 \\ \text { significant } & 0.01>P>0.001 \\ \text { highly significant } & 0.001>P\end{array}$

The error of the methods used for electrolyte, metabolite and enzyme determinations has been calculated according to the formula $\sqrt{\frac{\Sigma d^{2}}{2 n}}$, where $d$ is the difference between duplicate determinations and $n$ the number of duplicate determinations. The coefficients of variations are given as per cent of mean values (Tables 2 and 3 ).

Student's t-test was used for statistical comparison between mean values of age groups. Analyses of regression were made using the method of least squares. The significance of the correlation coefficients ( $r$ ) was calculated by testing the hypothesis $\mathbf{r}=\mathbf{0}$. Most statistical calculations were performed on an Olivetti P 101 desk computer.

\section{Methodological errors}

Electrolytes and total water. The accuracy of the methods for electrolyte determination $\left(\mathrm{Na}^{+}, \mathrm{K}^{+}\right.$and $\left.\mathrm{Mg}^{2+}\right)$, based on duplicate determinations from 1 wet ashed biopsy specimen, is shown in Table 2. The coefficient of variation was $3.1 \%$ for $\mathrm{Na}^{+}, 2.5 \%$ for

Table 2. Error of the method for electrolyte determinations. A. Error based on duplicate analyses of samples from 20 horses. B. Total error based on determination made from duplicate biopsies from the same muscle from 20 horses.

\begin{tabular}{|c|c|c|c|c|c|c|c|c|}
\hline & \multicolumn{4}{|c|}{$\mathbf{A}$} & \multicolumn{4}{|c|}{ B } \\
\hline & range & $\mathbf{m}$. & s & $\begin{array}{c}\text { coeff. of } \\
\text { variation } \\
\%\end{array}$ & $\overline{\text { range }}$ & $\mathrm{m}$. & $\mathbf{s}$ & $\begin{array}{c}\text { coeff. of } \\
\text { variation } \\
\%\end{array}$ \\
\hline $\begin{array}{l}\mathrm{Na}^{+} \\
\text {meq. } \times \mathrm{kg}^{-1}\end{array}$ & $16.3-33.7$ & 26.1 & 0.8 & 3.1 & $16.5-34.5$ & 24.8 & 3.1 & 12.3 \\
\hline $\begin{array}{l}\mathrm{K}^{+} \\
\text {meq. } \times \mathrm{kg}^{-1}\end{array}$ & $76.4-95.2$ & 86.6 & 2.5 & 2.5 & $82.7-112.9$ & 95.4 & 3.3 & 3.5 \\
\hline $\begin{array}{l}\mathrm{Mg}^{2+} \\
\text { meq. } \times \mathrm{kg}^{-1}\end{array}$ & $16.4-26.7$ & 20.1 & 1.0 & 5.0 & $16.8-24.1$ & 19.4 & 1.2 & 6.2 \\
\hline $\begin{array}{l}\mathrm{H}_{2} \mathrm{O} \\
\%\end{array}$ & - & - & - & 一 & $72.9-76.1$ & 74.7 & 0.8 & 1.0 \\
\hline
\end{tabular}


$\mathrm{K}^{+}$and $5.0 \%$ for $\mathrm{Mg}^{2+}$. The total variation, which depends on the variation due to sampling, weighing, biological variations and analytical errors, was calculated from results obtained from duplicate biopsy specimens taken on the same occasion. The coefficient of variation with this procedure was $12.3 \%$ for $\mathrm{Na}^{+}$, $3.5 \%$ for $\mathrm{K}^{+}$and $6.2 \%$ for $\mathrm{Mg}^{2+}$. The coefficient of variation for total water based on determinations made from duplicate biopsies, was $1.0 \%$. The blood content of 3 repeated biopsy specimens was calculated after keeping the specimens in $0.2 \mathrm{ml}$ of physiological saline $(\mathrm{NaCl})$. The red blood cell content was determined in the saline suspension in a Bürker chamber. Assuming capillary haematocrit, the average blood content could be calculated to 3.8 (range 3.2-4.6) $\mathrm{ml} \times \mathrm{kg}^{-1}$ wet weight.

Metabolites. The accuracy of the methods for metabolite determinations is shown in Table 3a. Calculations were usually based on duplicate determinations made from single biopsies. The coefficient of variation for glycogen was $5.7 \%$ at the lowest

T a b l e $3 \mathrm{a}$. The methodological error for determination of glycogen, G-6-P, glucose, lactate, ATP and CP in 1 biopsy specimen based on duplicate analyses.

\begin{tabular}{|c|c|c|c|c|c|}
\hline & $\mathbf{n}$ & $\begin{array}{c}\text { Range } \\
\text { mmol } \times \text { kg-1 }\end{array}$ & $\mathrm{m}$. & s & $\begin{array}{c}\text { Coeff. of } \\
\text { variation } \\
\%\end{array}$ \\
\hline $\begin{array}{l}\text { Glycogen } \\
\text { (glucose units) }\end{array}$ & $\begin{array}{l}20 \\
25 \\
25 \\
25\end{array}$ & $\begin{array}{c}10-49 \\
50-89 \\
90-129 \\
130-169\end{array}$ & $\begin{array}{r}39 \\
72 \\
112 \\
140\end{array}$ & $\begin{array}{l}2.2 \\
2.5 \\
3.1 \\
4.7\end{array}$ & $\begin{array}{l}5.7 \\
3.4 \\
2.8 \\
3.4\end{array}$ \\
\hline G-6-P & 25 & $0.2-2.8$ & 0.9 & 0.07 & 7.5 \\
\hline Glucose & 25 & $0.4-4.7$ & 1.6 & 0.10 & 6.3 \\
\hline Lactate & $\begin{array}{l}25 \\
25 \\
25 \\
11 \\
10\end{array}$ & $\begin{array}{c}0-5 \\
6-10 \\
11-15 \\
16-20 \\
21-25\end{array}$ & \begin{tabular}{r|r|}
2.8 & \\
7.1 & 12.3 \\
16.5 & \\
22.4 &
\end{tabular} & $\begin{array}{l}0.21 \\
0.25 \\
0.39 \\
0.32 \\
0.51\end{array}$ & $\begin{array}{l}7.5 \\
3.5 \\
3.2 \\
1.9 \\
2.3\end{array}$ \\
\hline ATP & $\begin{array}{l}25 \\
25 \\
25\end{array}$ & $\begin{array}{l}1.7-3.2 \\
3.3-4.8 \\
4.9-6.4\end{array}$ & $\begin{array}{l}2.4 \\
4.2 \\
5.5\end{array}$ & $\begin{array}{l}0.15 \\
0.27 \\
0.32\end{array}$ & $\begin{array}{l}6.3 \\
6.4 \\
5.8\end{array}$ \\
\hline CP & $\begin{array}{l}25 \\
25 \\
20\end{array}$ & $\begin{array}{r}3-12 \\
13-22 \\
23-32\end{array}$ & $\begin{array}{r}9.4 \\
18.0 \\
25.7\end{array}$ & $\begin{array}{l}0.54 \\
1.04 \\
2.08\end{array}$ & $\begin{array}{l}5.7 \\
5.8 \\
8.1\end{array}$ \\
\hline
\end{tabular}


concentration and $3.4 \%$ at the highest concentration. The glycogen content of horse muscle is usually in the 90 to $129 \mathrm{mmol} \times$ $\mathrm{kg}^{-1}$ range where the coefficient of variation is the least $(2.8 \%)$. The coefficient of variation was $7.5 \%$ for G-6-P and $6.3 \%$ for glucose. Lactate had the highest coefficient of variation in the lowest $0-5 \mathrm{mmol}$ group $(7.5 \%$ ). The higher the lactate concentration, the lower the coefficient of variation. ATP and CP had about the same coefficient of variation in all ranges, except at the highest CP concentration for which a value of $8.1 \%$ was obtained. The coefficient of variation was $5.4 \%$ for glycogen and $10.0 \%$ for lactate, including both sampling variation and errors in chemical determination.

Enzymes. The methodological error for SDH and PFK was calculated on the basis of duplicate determinations made from single biopsies. The coefficient of variation was $2 \%$ for SDH and $2.4 \%$ for PFK (Table $3 \mathrm{~b}$ ).

Table 3 b. The methodological error for SDH and PFK determinations in 1 biopsy specimen from 25 horses.

\begin{tabular}{|c|c|c|c|c|}
\hline & $\frac{\text { Range }}{\mu \mathrm{mol} \times(\mathrm{g} \times \min )^{-1}}$ & $\mathrm{~m}$. & $\mathbf{s}$ & $\begin{array}{c}\text { Coeff. of } \\
\text { variation } \\
\%\end{array}$ \\
\hline SDH & $2.5-12.6$ & 6.0 & 0.12 & 2.0 \\
\hline PFK & $14.5-42.3$ & 24.8 & 0.59 & 2.4 \\
\hline
\end{tabular}

\section{RESULTS}

\section{Relative fibre composition and fibre area}

Three major fibre types were identified, 1 possessing low and the other 2 high myofibrillar ATPase staining intensity. Since the ATPase staining reflects the contractile properties of the fibre (Barnard et al. 1971), horse muscle must be composed of fibres with slow twitch ( $\left.\mathrm{S}^{\prime} \mathrm{T}\right)$ and fast twitch (FT) characteristics. On the basis of NADH-diaphorase staining intensity, which reflects the oxidative capacity of fibres (Novikoff et al. 1961), the ST fibre was found to be highly oxidative. Two types of fast twitch fibres were identified, 1 possessing greater oxidative capacity than the other. Thus, a fast twitch fibre with a high oxidative capacity (FTH) and a fast twitch fibre with a low oxidative capacity (FT) were identified. The NADH-diaphorase staining pattern of the FTH fibre was not always as intense as 

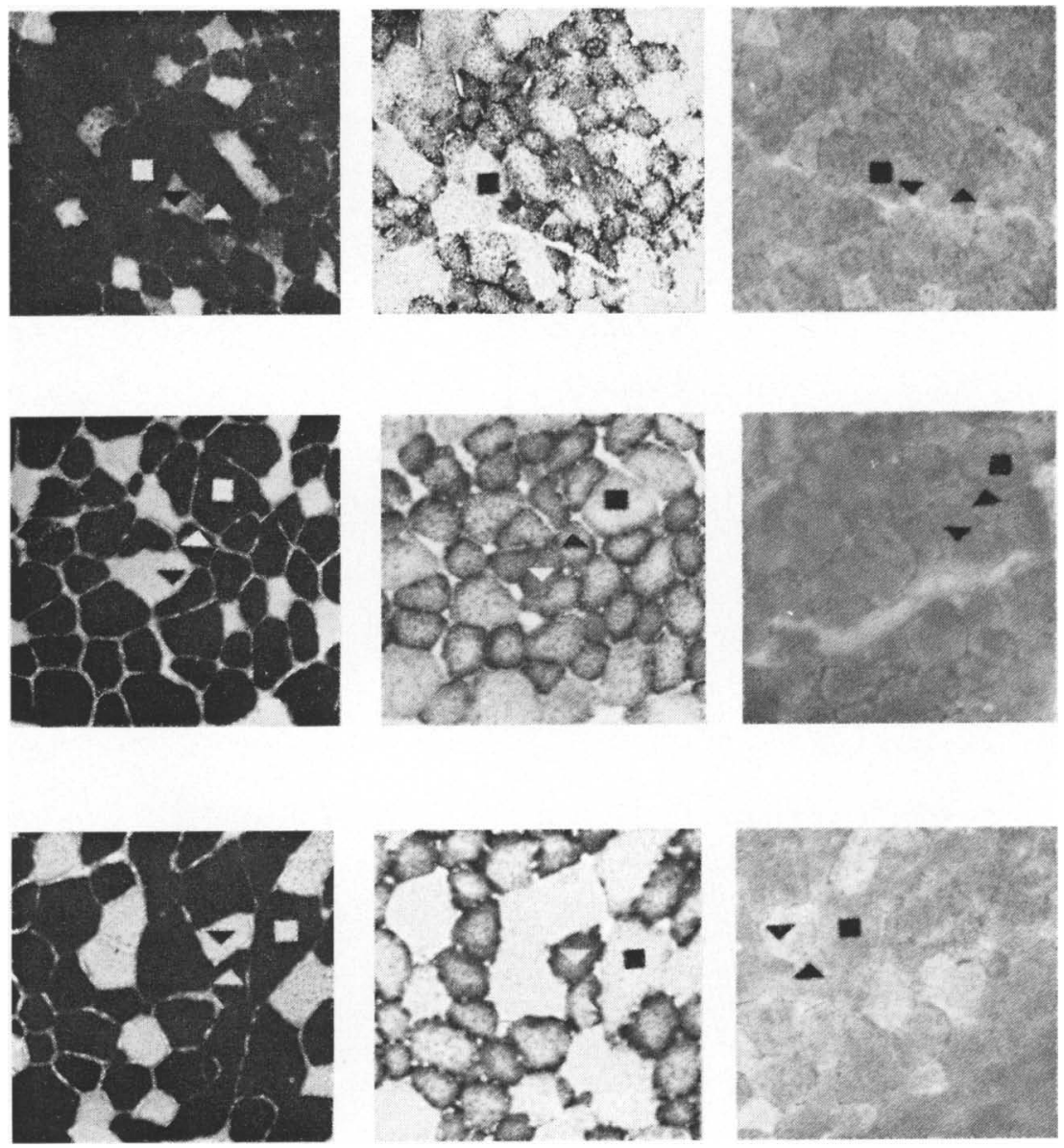

F i g u r e 1. Photomicrographs of serial sections $(\times 85)$ of biopsy specimens from the gluteus medius muscle of standardbred horses at 3 different ages. The ages are (from top to bottom) $1 / 2,2$ and 6 years. Left to right: serial sections stained for myosin ATPase, NADH-diaphorase and glycogen (PAS), respectively. 


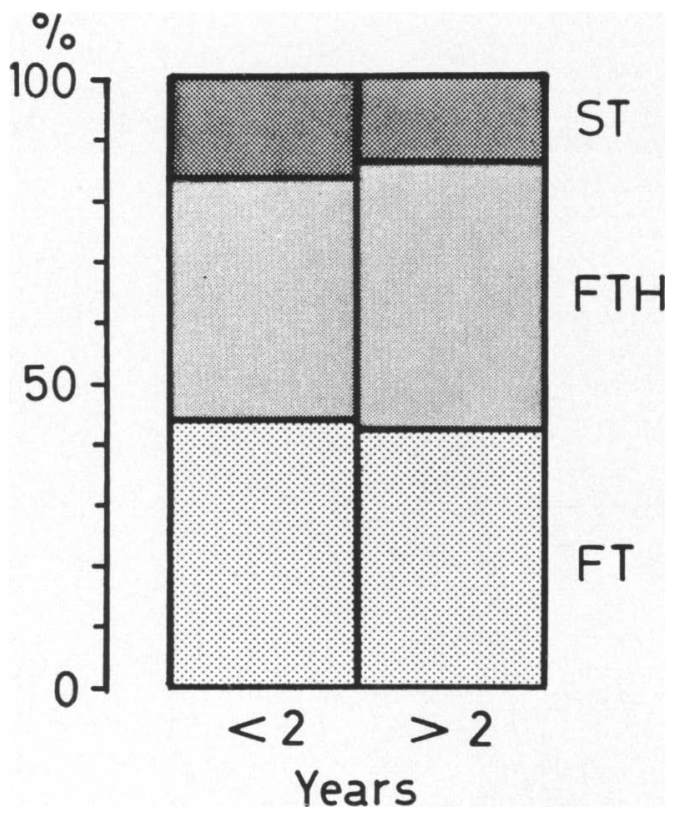

F i g u r e 2. Relative area occupied by each of the 3 major fibre types found in the gluteus medius muscle of standardbred horses below and above the age af 2 years. 
that of the ST fibre, showing that some ST fibres have a greater oxidative capacity than FTH fibres (Table 1, Fig. 1).

In the youngest horses ( $1 / 2$ year), which were still untrained, the average $f \mathbf{i b r e} d \mathbf{i} t \mathbf{r} \mathbf{i b} \mathbf{t} \mathrm{i}$ on in the gluteus medius muscle was 24 (range $13-38$ ) \% ST, 49 (range 34-57) \% FTH and 27 (range 25-30) \% FT fibres. The relative percentage of the total fibre population consisting of ST fibres was the same at different ages, but FTH fibres increased by $5 \%$ and FT fibres decreased by $6 \%$ when the youngest ( $1 / 2$ year) and oldest ( $4-8$ years) horse groups were compared. A statistical comparison (Student's t-test) between mean differences of FTH and FT fibre percentages of untrained and trained horses revealed an almost significant $(0.05>\mathrm{P}>0.01)$ difference. In the oldest and, consequently, the best-trained horses, the fibre distribution was 24 (range 16-33) \% ST, 54 (range 35-64) \% FTH and 22 (range 7-37) \% FT fibres (Table 4).

The $\mathrm{r}$ e $\mathrm{l}$ a $\mathrm{t} \mathrm{i}$ e a $\mathrm{r}$ e a of the 3 fibre types was quite different and did not change with age. The mean fibre population at all ages was $23.4 \%$ of the area for ST, $25.3 \%$ for FTH and $51.3 \%$ for FT fibres.

The cross-section a l f i b r e a r e a in the whole group of untrained horses ( $1 / 2-2$ years) was $2410 \mu \mathrm{m}^{2}$ for ST, $2880 \mu \mathrm{m}^{2}$ for FTH and $5170 \mu \mathrm{m}^{2}$ for FT fibres. With age and training, the area of fibres increased by $15 \%$ for ST and FTH and by $25 \%$ for FT (Table 4). Even though the area of FT fibres was larger than the area of both FTH and ST fibres, the highest relative percentage of the 3 fibre types consisted of FTH fibres. Consequently the high percentage of FTH fibres need not necessarily indicate that the muscle's total cross-sectional fibre area is mainly composed of FTH fibres. In the untrained horses $(1 / 2-2$ years), $16.7 \%$ of the total cross-sectional area consisted of ST fibres, $39.6 \%$ of FTH and $43.7 \%$ of FT fibres. However, the total cross-sectional area of ST fibres in the trained horses (2-8year olds) decreased to $14.6 \%$, FT fibres to $42.8 \%$ and the FTH fibres increased to $42.6 \%$ (Fig. 2).

P A S s t a i n i n in te $n$ s it y, reflecting glycogen distribution, displayed differences between fibres. In trained horses (4-8-year olds), $\mathbf{1 0 0} \%$ of the FT fibres were rated as dark while $78 \%$ of the FTH fibres displayed dark and $22 \%$ moderate staining; $25 \%$ of the ST fibres displayed dark, $71 \%$ moderate and $4 \%$ light staining. 
T a b l e 4. Mean value, $s$ and range for muscle enzyme activity, muscle

fibre composition and muscle area of the gluteus medius muscle in untrained and trained standardbred horses of different ages.

\begin{tabular}{|c|c|c|c|c|c|}
\hline & & \multicolumn{2}{|c|}{ Untrained } & \multicolumn{2}{|c|}{ Trained } \\
\hline & & $\begin{array}{c}1 / 2 \\
\text { year }\end{array}$ & $\begin{array}{c}1-2 \\
\text { years }\end{array}$ & $\begin{array}{l}2-4 \\
\text { years }\end{array}$ & $\begin{array}{c}4-8 \\
\text { years }\end{array}$ \\
\hline $\begin{array}{c}\text { SDH } \\
\mu \mathrm{mol} \times(\mathrm{g} \times \mathrm{min})^{-1}\end{array}$ & $\begin{array}{l}\mathrm{m} . \\
\mathrm{s} \\
\text { range } \\
\mathrm{n}\end{array}$ & $\begin{array}{c}6.1 \\
1.08 \\
4.6--7.6 \\
5\end{array}$ & $\begin{array}{c}7.3 \\
1.99 \\
5.2-12.7 \\
8\end{array}$ & $\begin{array}{c}10.7 \\
3.02 \\
6.5-16.5 \\
11\end{array}$ & $\begin{array}{c}13.6 \\
2.80 \\
10.0-18.3 \\
7\end{array}$ \\
\hline $\begin{array}{c}\text { PFK } \\
\mu \mathrm{mol} \times(\mathrm{g} \times \mathrm{min})^{-1}\end{array}$ & $\begin{array}{l}\mathrm{m} . \\
\mathrm{s} \\
\text { range } \\
\mathrm{n}\end{array}$ & $\begin{array}{c}47.1 \\
12.88 \\
38.9-7.0 .0 \\
5\end{array}$ & $\begin{array}{c}62.6 \\
7.46 \\
51.8-76.5 \\
8\end{array}$ & $\begin{array}{c}70.3 \\
8.79 \\
53.0-85.3 \\
11\end{array}$ & $\begin{array}{c}59.8 \\
6.73 \\
51.4-66.4 \\
7\end{array}$ \\
\hline $\begin{array}{c}\text { Fibre composition } \\
\text { ST } \\
\%\end{array}$ & $\begin{array}{l}\mathrm{m} . \\
\mathrm{s} \\
\text { range } \\
\mathrm{n}\end{array}$ & $\begin{array}{c}24 \\
9.4 \\
13-38 \\
4\end{array}$ & $\begin{array}{c}24 \\
3.6 \\
20-30 \\
8\end{array}$ & $\begin{array}{c}24 \\
4.9 \\
15-31 \\
17\end{array}$ & $\begin{array}{c}24 \\
5.8 \\
16-33 \\
12\end{array}$ \\
\hline $\begin{array}{l}\text { FTH } \\
\%\end{array}$ & $\begin{array}{l}\mathrm{m} . \\
\mathrm{s} \\
\text { range } \\
\mathrm{n}\end{array}$ & $\begin{array}{c}49 \\
8.1 \\
34-57 \\
4\end{array}$ & $\begin{array}{c}49 \\
3.1 \\
46-55 \\
8\end{array}$ & $\begin{array}{c}52 \\
7.0 \\
38 \longrightarrow 64 \\
17\end{array}$ & $\begin{array}{c}54 \\
9.1 \\
35-64 \\
12\end{array}$ \\
\hline $\begin{array}{l}\text { FT } \\
\%\end{array}$ & $\begin{array}{l}\mathrm{m} . \\
\mathrm{s} \\
\text { range } \\
\mathrm{n}\end{array}$ & $\begin{array}{c}27 \\
2.1 \\
25-30 \\
4\end{array}$ & $\begin{array}{c}27 \\
3.3 \\
24-34 \\
8\end{array}$ & $\begin{array}{c}24 \\
6.3 \\
15-39 \\
17\end{array}$ & $\begin{array}{c}22 \\
8.6 \\
7-37 \\
12\end{array}$ \\
\hline $\begin{array}{c}\text { Rel. fibre area } \\
\text { ST } \\
\%\end{array}$ & $\begin{array}{l}\mathrm{m} . \\
\mathrm{s} \\
\text { range } \\
\mathrm{n}\end{array}$ & $\begin{array}{c}24.7 \\
3.61 \\
22-29 \\
3\end{array}$ & $\begin{array}{r}23.0 \\
2.54 \\
19-26 \\
5\end{array}$ & $\begin{array}{c}23.5 \\
\frac{-}{22-25} \\
2\end{array}$ & $\begin{array}{c}22.3 \\
2.08 \\
20-24 \\
3\end{array}$ \\
\hline $\begin{array}{l}\text { FTH } \\
\%\end{array}$ & $\begin{array}{l}\mathrm{m} . \\
\mathrm{s} \\
\text { range } \\
\mathrm{n}\end{array}$ & $\begin{array}{c}26.1 \\
5.00 \\
22-32 \\
3\end{array}$ & $\begin{array}{c}25.4 \\
1.82 \\
23-28 \\
5\end{array}$ & $\begin{array}{c}\frac{23.0}{22-} \\
\frac{2}{2}\end{array}$ & $\begin{array}{r}26.7 \\
4.04 \\
23-31 \\
3\end{array}$ \\
\hline $\begin{array}{l}\text { FT } \\
\%\end{array}$ & $\begin{array}{l}\mathrm{m} . \\
\mathrm{s} \\
\text { range } \\
\mathrm{n}\end{array}$ & $\begin{array}{c}49.2 \\
8.50 \\
39-56 \\
3\end{array}$ & $\begin{array}{c}51.6 \\
3.20 \\
48-56 \\
5\end{array}$ & $\begin{array}{c}53.5 \\
\frac{-}{53-54} \\
2\end{array}$ & $\begin{array}{r}51.0 \\
6.00 \\
45-57 \\
3\end{array}$ \\
\hline $\begin{array}{c}\text { Fibre area } \\
\text { ST } \\
\mu \mathrm{m}^{2}\end{array}$ & $\begin{array}{l}\mathrm{m} . \\
\mathrm{s} \\
\text { range } \\
\mathrm{n}\end{array}$ & $\begin{array}{c}2539 \\
535.5 \\
2058-3116 \\
3\end{array}$ & $\begin{array}{c}2391 \\
383.3 \\
1862-2940 \\
5\end{array}$ & $\begin{array}{c}2646 \\
\frac{-}{2450-2842} \\
2\end{array}$ & $\begin{array}{c}2940 \\
339.5 \\
2744-3332 \\
3\end{array}$ \\
\hline $\begin{array}{l}\text { FTH } \\
\mu \mathrm{m}^{2}\end{array}$ & $\begin{array}{l}\mathrm{m} . \\
\mathrm{s} \\
\text { range } \\
\mathrm{n}\end{array}$ & $\begin{array}{c}2689 \\
692.4 \\
2058-3430 \\
3\end{array}$ & $\begin{array}{c}2664 \\
306.0 \\
2352-3038 \\
5\end{array}$ & $\begin{array}{c}2597 \\
\frac{-}{2548-2646} \\
2\end{array}$ & $\begin{array}{c}3462 \\
299.4 \\
3136-3724 \\
3\end{array}$ \\
\hline $\begin{array}{l}\text { FT } \\
\mu \mathrm{m}^{2}\end{array}$ & $\begin{array}{l}\mathrm{m} . \\
\mathrm{s} \\
\text { range } \\
\mathrm{n}\end{array}$ & $\begin{array}{c}4791 \\
640.4 \\
4116 \_5390 \\
3\end{array}$ & $\begin{array}{c}5272 \\
223.5 \\
4998-5488 \\
5\end{array}$ & $\begin{array}{c}6027 \\
- \\
5880-6174 \\
2\end{array}$ & $\begin{array}{c}6762 \\
1508.7 \\
5096-8036 \\
3\end{array}$ \\
\hline
\end{tabular}




\section{Differences in fibre composition between various muscles}

Minor variations were observed in the percentage of ST fibres in different muscles (Table 7). The quadriceps femoris muscle displayed a small proportion of FTH fibres $(34 \%)$, whereas the other muscles examined displayed differences as compared to the gluteus medius. Thus, the proportion of FT fibres was larger in the quadriceps femoris muscle than in the other muscles.

Total water, electrolytes and protein content in the gluteus medius muscle

Total water content was $74.9 \%$ for all groups of horses (Table 5), and no significant difference was seen with increasing age. $\mathrm{Na}^{+}$content was found to be the same up to 4 years with a mean value of 21.3 (range $21.2-21.4$ ) meq. $\times \mathrm{kg}^{-1}$. The $\mathrm{Na}^{+}$content increased after 4 years of age and was $21 \%$ higher in the 4 -8-year old group than in the 0-4-year old horses. The correlation between age and muscular $\mathrm{Na}^{+}$was statistically almost

T a b l e 5. Muscle water content and some muscle electrolytes in the gluteus medius muscle of standardbred horses of different ages. Mean value, $s$, range and number of examined horses are given.

\begin{tabular}{|c|c|c|c|c|c|c|c|}
\hline \multirow{2}{*}{$\begin{array}{l}\text { Muscle } \\
\text { constituents } \\
\text { per kg of } \\
\text { wet muscle }\end{array}$} & & \multicolumn{5}{|c|}{ Age (years) } & \multirow[b]{2}{*}{ Total group } \\
\hline & & $0-1$ & $1-2$ & $2-3$ & $3-4$ & $4-8$ & \\
\hline $\begin{array}{c}\mathrm{H}_{2} \mathrm{O} \\
\%\end{array}$ & $\begin{array}{l}\mathrm{m} . \\
\mathbf{s} \\
\text { range } \\
\mathrm{n}\end{array}$ & $\begin{array}{c}75.0 \\
1.22 \\
73.7-76.6 \\
5\end{array}$ & $\begin{array}{c}74.9 \\
0.62 \\
74.4-76.0 \\
6\end{array}$ & $\begin{array}{c}74.9 \\
0.13 \\
74.7-75.0 \\
4\end{array}$ & $\begin{array}{c}74.6 \\
1.19 \\
74.3-75.0 \\
4\end{array}$ & $\begin{array}{c}74.8 \\
1.14 \\
74.2-75.7 \\
7\end{array}$ & $\begin{array}{c}74.9 \\
1.07 \\
73.7-76.6 \\
26\end{array}$ \\
\hline $\begin{array}{l}\mathrm{Na}^{+} \\
\text {meq. }\end{array}$ & $\begin{array}{l}\text { m. } \\
\text { s } \\
\text { range } \\
\text { n }\end{array}$ & $\begin{array}{c}21.4 \\
4.01 \\
17.8-27.3 \\
5\end{array}$ & $\begin{array}{c}21.2 \\
1.74 \\
18.7-23.4 \\
6\end{array}$ & $\begin{array}{c}21.4 \\
4.53 \\
17.4-26.2 \\
4\end{array}$ & $\begin{array}{c}21.2 \\
4.46 \\
17.4-26.2 \\
4\end{array}$ & $\begin{array}{c}25.8 \\
4.72 \\
18.4-31.6 \\
12\end{array}$ & $\begin{array}{c}23.1 \\
4.49 \\
17.4-31.6 \\
31\end{array}$ \\
\hline $\begin{array}{l}\mathbf{K}^{+} \\
\text {meq. }\end{array}$ & $\begin{array}{l}\text { m. } \\
\mathbf{s} \\
\text { range } \\
\text { n }\end{array}$ & $\begin{array}{c}100.4 \\
10.65 \\
88.2-116.2 \\
5\end{array}$ & $\begin{array}{c}96.0 \\
7.35 \\
86.3-106.0 \\
6\end{array}$ & $\begin{array}{c}91.5 \\
2.84 \\
85.6-95.2 \\
4\end{array}$ & $\begin{array}{c}90.4 \\
5.02 \\
85.6-95.2 \\
4\end{array}$ & $\begin{array}{c}86.6 \\
5.11 \\
76.2 — 94.0 \\
12\end{array}$ & $\begin{array}{c}91.6 \\
7.97 \\
76.2-116.2 \\
31\end{array}$ \\
\hline $\begin{array}{c}\mathrm{Mg}^{2+} \\
\text { meq. }\end{array}$ & $\begin{array}{l}\text { m. } \\
\mathbf{s} \\
\text { range } \\
\mathrm{n}\end{array}$ & $\begin{array}{c}18.7 \\
1.66 \\
17.3-21.0 \\
4\end{array}$ & $\begin{array}{c}19.1 \\
1.15 \\
17.6-20.5 \\
5\end{array}$ & $\begin{array}{c}17.9 \\
1.10 \\
16.9-22.4 \\
3\end{array}$ & $\begin{array}{c}20.5 \\
2.60 \\
16.9-22.4 \\
4\end{array}$ & $\begin{array}{c}18.4 \\
1.37 \\
17.4-21.0 \\
6\end{array}$ & $\begin{array}{c}18.9 \\
1.69 \\
16.8-22.4 \\
22\end{array}$ \\
\hline
\end{tabular}


significant $(0.05>\mathrm{P}>0.01, \mathrm{r}=0.31)$. In the 4-8-year old group the mean value was $25.8 \mathrm{meq} . \times \mathrm{kg}^{-1}$ (Table 5 ).

$\mathrm{K}^{+}$content decreased by $14 \%$ with age from a mean value of 100.4 meq. $\times \mathrm{kg}^{-1}$ in the age group $0-1$ year to 86.6 (range 86.294.0) meq. $\times \mathrm{kg}^{-1}$ in the oldest group. The correlation coefficient ( $r)$ was 0.62 and highly significant $(P<0.001)$.

The $\mathrm{Mg}^{2+}$ content showed no significant change with increasing age, and was 18.9 (range $16.8-22.4$ ) meq. $\times \mathrm{kg}^{-1}$ wet muscle calculated for all groups. Protein content amounted to 219 (range 199-239) $\mathrm{g} \times \mathrm{kg}^{-1}$ and was not found to vary among horses of different ages.

\section{Muscle metabolites}

The glycoge $\mathrm{n}$ content of the gluteus medius muscle in $1 / 2$-year old horses (Table 6) averaged 95 (range 83-105) mmol of glucose units $\times \mathrm{kg}^{-1}$ of wet muscle. In 5-8-year old horses glycogen averaged 126 (range $78-154$ ) $\mathrm{mmol}$ of glucose units $\times \mathrm{kg}^{-1}$ of wet muscle, representing a $33 \%$ higher value in the oldest age group. The increase with age was highly significant $(\mathrm{P}<0.001, \mathrm{r}=0.57)$. The $\mathrm{G}-6-\mathrm{P}$ concentration ranged from 1.2 to $0.4 \mathrm{mmol} \times \mathrm{kg}^{-1}$ of wet muscle in all groups (Table 6 ). The g l u c o s e concentration was the same at all ages with a mean value of 0.6 (range $0.5-0.8) \mathrm{mmol} \times \mathrm{kg}^{-1}$ of wet muscle calculated for the whole material (Table 6). The muscle concentration of $\mathrm{p} \mathrm{y} \mathrm{r} \mathrm{u} \mathrm{vat} \mathrm{e} \mathrm{decreased} \mathrm{with} \mathrm{age} \mathrm{from} 0.49 \mathrm{mmol} \times \mathrm{kg}^{-1}$ of wet muscle in the youngest age group to $0.03 \mathrm{mmol} \times \mathrm{kg}^{-1}$ of wet muscle in the oldest group. The decrease with age was highly significant $(\mathrm{P}<0.001, \mathrm{r}=0.92)$. There was also a decrease in muscle $\mathrm{lactat}$ e concentration due to age and training. The decrease amounted to $47 \%$, i.e. from 5.5 (range 4.1-8.2) to 2.9 (range 1.5-5.5) mmol $\times \mathrm{kg}^{-1}$ of wet muscle between the $1 / 2$ and 5 -8-year olds. A correlation coefficient of 0.62 was calculated which proved to be highly significant $(\mathrm{P}<0.001)$.

\section{Variation in glycogen and lactate during 1 day and 1 week}

When biopsies were taken at 3-hr. intervals during the day and analyzed, mean glycogen values for 4 horses ranged from 101 to $104 \mathrm{mmol} \times \mathrm{kg}^{-1}$ of wet muscle. No significant differences were observed between the different sampling occasions. In biopsy specimens taken each day in a week in which the horses 
carried out their daily training routines (Fig. 3) a highly significant decrease in glycogen content $(P<0.001)$, from 124 to 95 mmol $\times \mathrm{kg}^{-1}$ wet muscle, was seen the day after the horse had performed maximal trotting. Forty-eight hrs. after maximal trotting, glycogen stores had been refilled, displaying a mean

T a b l e 6. Muscle metabolites of gluteus medius muscle in standardbred horses of different ages. Mean value, s, range and number of horses are given.

\begin{tabular}{|c|c|c|c|c|c|c|c|}
\hline \multirow{2}{*}{$\begin{array}{l}\text { Muscle } \\
\text { constituents } \\
\text { mmol } \times \mathbf{k g}^{-1} \\
\text { wet muscle }\end{array}$} & & \multicolumn{5}{|c|}{ Age (years) } & \multirow{2}{*}{$5-8$} \\
\hline & & $0-1$ & $1-2$ & $2-3$ & $3-4$ & $4-5$ & \\
\hline $\begin{array}{l}\text { Glycogen } \\
\text { (glucose units) }\end{array}$ & $\begin{array}{l}\mathrm{m} . \\
\mathrm{s} \\
\text { range } \\
\mathrm{n}\end{array}$ & $\begin{array}{c}95 \\
9.7 \\
83-105 \\
6\end{array}$ & $\begin{array}{c}98 \\
19.6 \\
68-134 \\
13\end{array}$ & $\begin{array}{c}107 \\
11.2 \\
89-118 \\
7\end{array}$ & $\begin{array}{c}110 \\
16.5 \\
87-141 \\
9\end{array}$ & $\begin{array}{c}122 \\
22.0 \\
87-175 \\
15\end{array}$ & $\begin{array}{c}126 \\
16.0 \\
78-154 \\
12\end{array}$ \\
\hline G-6-P & $\begin{array}{l}\mathrm{m} . \\
\mathrm{s} \\
\text { range } \\
\mathrm{n}\end{array}$ & $\begin{array}{c}1.1 \\
1.21 \\
0.2-3.1 \\
5\end{array}$ & $\begin{array}{c}1.2 \\
0.51 \\
0.3-1.7 \\
9\end{array}$ & $\begin{array}{c}0.8 \\
0.15 \\
0.4-1.3 \\
7\end{array}$ & $\begin{array}{c}0.7 \\
0.46 \\
0.2-1.2 \\
4\end{array}$ & $\begin{array}{c}0.4 \\
0.31 \\
0.1-1.0 \\
7\end{array}$ & $\begin{array}{c}0.8 \\
0.49 \\
0.2-1.4 \\
5\end{array}$ \\
\hline Glucose & $\begin{array}{l}\mathrm{m} . \\
\mathrm{s} \\
\text { range } \\
\mathrm{n}\end{array}$ & $\begin{array}{c}0.7 \\
0.10 \\
0.6-0.8 \\
5\end{array}$ & $\begin{array}{c}0.6 \\
0.25 \\
0.3-1.1 \\
8\end{array}$ & $\begin{array}{c}0.7 \\
0.17 \\
0.6-0.9 \\
4\end{array}$ & $\frac{0.5}{0.4-0.6}$ & $\begin{array}{c}0.8 \\
0.26 \\
0.4-1.2 \\
6\end{array}$ & $\frac{0.5}{-}$ \\
\hline Pyruvate & $\begin{array}{l}\mathrm{m} . \\
\mathrm{s} \\
\text { range } \\
\mathrm{n}\end{array}$ & $\frac{0.49}{-}$ & $\begin{array}{c}0.27 \\
0.015 \\
0.25-0.28 \\
3\end{array}$ & $\frac{0.21}{-}$ & $\begin{array}{c}0.13 \\
0.08-0.18 \\
2\end{array}$ & $\begin{array}{l}- \\
- \\
-\end{array}$ & $\begin{array}{c}0.03 \\
\frac{-02-0.04}{3}\end{array}$ \\
\hline Lactate & $\begin{array}{l}\mathrm{m} . \\
\mathrm{s} \\
\text { range } \\
\mathrm{n}\end{array}$ & $\begin{array}{c}5.5 \\
1.40 \\
4.1-8.2 \\
6\end{array}$ & $\begin{array}{c}4.7 \\
1.02 \\
3.0-7.4 \\
13\end{array}$ & $\begin{array}{c}3.8 \\
0.33 \\
3.4-4.3 \\
77\end{array}$ & $\begin{array}{c}3.4 \\
0.96 \\
2.1-5.2 \\
\quad 9\end{array}$ & $\begin{array}{c}2.9 \\
1.22 \\
1.5-6.2 \\
15\end{array}$ & $\begin{array}{l}2.9 \\
1.18 \\
1.5-5.5 \\
12\end{array}$ \\
\hline ATP & $\begin{array}{l}\mathrm{m} . \\
\mathbf{s} \\
\text { range } \\
\mathrm{n}\end{array}$ & $\begin{array}{c}4.6 \\
0.61 \\
3.7-5.1 \\
5\end{array}$ & $\begin{array}{c}4.7 \\
0.56 \\
3.6-5.3 \\
9\end{array}$ & $\begin{array}{c}4.9 \\
0.64 \\
3.7-5.5 \\
7\end{array}$ & $\begin{array}{c}5.1 \\
0.81 \\
3.6-6.6 \\
9\end{array}$ & $\begin{array}{c}4.8 \\
0.58 \\
3.8-5.8 \\
12\end{array}$ & $\begin{array}{c}5.1 \\
0.59 \\
3.9-5.9 \\
11\end{array}$ \\
\hline CP & $\begin{array}{l}\text { m. } \\
\text { s } \\
\text { range } \\
\text { n }\end{array}$ & $\begin{array}{c}16.7 \\
3.47 \\
12.2-21.5 \\
5\end{array}$ & $\begin{array}{c}17.1 \\
2.00 \\
14.5-19.7 . \\
9\end{array}$ & $\begin{array}{c}18.7 \\
4.15 \\
13.5-25.1 \\
7\end{array}$ & $\begin{array}{c}15.5 \\
2.32 \\
12.2-17.6 \\
4\end{array}$ & $\begin{array}{c}17.1 \\
3.27 \\
11.5-19.8 \\
8\end{array}$ & $\begin{array}{c}16.9 \\
3.47 \\
12.3-23.4 \\
10\end{array}$ \\
\hline
\end{tabular}




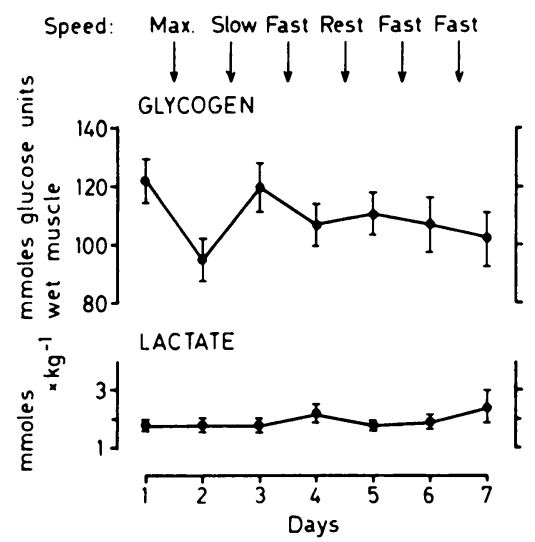

Figure 3. Glycogen and lactate concentrations in the gluteus medius muscle of 6 standardbred horses trained daily at maximal $\left(1 \mathrm{~min} .24 \mathrm{sec} . \times \mathrm{km}^{-1}\right)$, fast $\left(2 \mathrm{~min} . \times \mathrm{km}^{-1}\right)$ or slow $(3 \mathrm{~min} .20$ sec. $\times \mathbf{k m}^{-1}$ ) trotting.

value of $120 \mathrm{mmol} \times \mathrm{kg}^{-1}$ of wet muscle. This mean value did not change significantly during the rest of the week when the horse only performed very light exercise.

\section{Enzyme activity at different ages and in various muscle groups}

SDH activity in the gluteus medius muscle was lowest in the untrained $1 / 2$-year old horses, displaying a mean value of 6.1 (range 4.6-7.6) $\mu \mathrm{mol} \times(\mathrm{g} \times \mathrm{min})^{-1}$. In highly trained, 4-8-year old horses, the mean value ranged from 10.0 to $18.3 \mu \mathrm{mol} \times(\mathrm{g} \times$ $\min )^{-1}$. The correlation between age and SDH activity was statistically highly significant $(P<0.001, r=0.65)$. There was also a difference in SDH activity between different muscles. The quadriceps femoris muscle (vastus lateralis) displayed about $50 \%$ less activity than the gluteus medius and the triceps brachii muscles, which had 12.2 and $11.3 \mu \mathrm{mol} \times(\mathrm{g} \times \mathrm{min})^{-1}$, respectively. The infraspinatus muscle displayed activity of $8.5 \mu \mathrm{mol} \times(\mathrm{g} \times$ $\min )^{-1}$, which was $28 \%$ less than in the gluteus medius muscle (Table 7).

PFK activity amounted to 47 (range 38.9-70.0) $\mu \mathrm{mol} \times(\mathrm{g} \times$ $\min )^{-1}$ in the youngest age group. Age and/or training produced an increase in the PFK activity to 70.3 (range 53.0-85.3) $\mu \mathrm{mol}$ $X(\mathrm{~g} \times \min )^{-1}$ in the 2-4-year old group. PFK activity then 
T a b le 7. Muscle fibre composition, muscle enzyme activities and ribonucleic acid (RNA) in different muscles of standardbred horses.

Mean value, $s$, range and number of examined horses are given.

\begin{tabular}{|c|c|c|c|c|c|c|c|}
\hline \multirow{2}{*}{ Muscle } & & \multicolumn{3}{|c|}{ Fibre composition } & \multirow{2}{*}{ 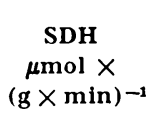 } & \multirow{2}{*}{ PFK } & \multirow{2}{*}{$\begin{array}{c}\text { RNA } \\
\mathbf{m g} \times \mathbf{g}^{-1}\end{array}$} \\
\hline & & $\begin{array}{l}\text { ST } \\
\%\end{array}$ & $\underset{\%}{\text { FTH }}$ & $\begin{array}{l}\text { FT } \\
\%\end{array}$ & & & \\
\hline Gluteus medius & $\begin{array}{l}\text { m. } \\
\text { s } \\
\text { range } \\
\text { n }\end{array}$ & $\begin{array}{c}26 \\
2.2 \\
23-28 \\
4\end{array}$ & $\begin{array}{c}45 \\
3.1 \\
42-49 \\
4\end{array}$ & $\begin{array}{c}29 \\
3.4 \\
24-31 \\
4\end{array}$ & $\begin{array}{c}12.2 \\
1.95 \\
9.3-14.5 \\
5\end{array}$ & $\begin{array}{c}46.3 \\
13.74 \\
27.0-60.2 \\
5\end{array}$ & $\begin{array}{c}1.2 \\
0.14 \\
0.9-1.6 \\
5\end{array}$ \\
\hline Vastus lateralis & $\begin{array}{l}\mathrm{m} . \\
\mathrm{s} \\
\text { range } \\
\mathrm{n}\end{array}$ & $\begin{array}{c}27 \\
5.7 \\
23-35 \\
4\end{array}$ & $\begin{array}{c}34 \\
7.3 \\
27-44 \\
4\end{array}$ & $\begin{array}{c}39 \\
8.9 \\
30-50 \\
4\end{array}$ & $\begin{array}{c}5.9 \\
2.82 \\
2.8-9.8 \\
5\end{array}$ & $\begin{array}{c}40.9 \\
10.91 \\
24.4-54.4 \\
55\end{array}$ & $\begin{array}{c}1.0 \\
0.15 \\
0.9-1.2 \\
3\end{array}$ \\
\hline Triceps brachii & $\begin{array}{l}\text { m. } \\
\text { s } \\
\text { range } \\
\mathrm{n}\end{array}$ & $\begin{array}{c}24 \\
4.7 \\
17--28 \\
4\end{array}$ & $\begin{array}{c}49 \\
10.0 \\
40-63 \\
4\end{array}$ & $\begin{array}{c}27 \\
9.5 \\
13-33 \\
4\end{array}$ & $\begin{array}{c}11.3 \\
3.21 \\
6.0-14.1 \\
5\end{array}$ & $\begin{array}{c}40.0 \\
9.73 \\
23.8-48.8 \\
5\end{array}$ & $\begin{array}{c}1.0 \\
0.25 \\
0.8-1.3 \\
3\end{array}$ \\
\hline Infraspinatus & $\begin{array}{l}\mathrm{m} . \\
\mathrm{s} \\
\text { range } \\
\mathrm{n}\end{array}$ & $\frac{23}{17-28}$ & $\frac{46}{40-53}$ & $\frac{31}{30-32}$ & $\frac{8.5}{6.8-10.1}$ & $\frac{21.2}{14.5-27.8}$ & $\frac{1.1}{1.0-1.2}$ \\
\hline
\end{tabular}

declined to an average of 59.8 (range 51.4-66.4) $\mu \mathrm{mol} \chi^{\prime}$ $(\mathrm{g} \times \mathrm{min})^{-1}$ in the trained $4-8$-year old group. The greatest PFK activity was found in the gluteus medius and the least activity in the infraspinatus muscle.

RNA displayed about the same mean value 1.1 (range 1.0 1.2) $\mathrm{mg} \times \mathrm{g}^{-1}$ in all age groups and muscles (Table 7 ).

\section{DISCUSSION}

A number of different systems for classifying mammalian skeletal muscle fibres have been reported in the past 10 years (Table 8). Recent investigations have shown that most mammalian muscles are composed of 3 major types of fibres when classified on the basis of contractile characteristics (myofibrillar ATPase staining), the oxidative capacity (SDH or NADH-diaphorase), myoglobin content and ultrastructure (Close 1972, Peter et al. 1972). The nomenclature for the different fibres 
Table 8. Nomenclature used by various authors in classifying mammalian skeletal muscle fibres. The nomenclature suggested in the present study, i.e. fast twitch (FT), fast twitch, high oxidative (FTH) and slow twitch (ST) fibres, has been used as the basis for comparisons.

\begin{tabular}{lccc}
\hline & \multicolumn{3}{c}{ Type of fibre } \\
\cline { 2 - 4 } & FT & FTH & ST \\
\hline Stein \& Padykula (1962) & A & C & B \\
Romanul (1964) & I & II & III \\
Henneman \& Olson (1965) & A & B & C \\
Padykula \& Gauthier (1967) & white & red & intermediate \\
Kugelberg \& Edström (1968) & A & B & C \\
Engel (1970) & II & II & I \\
Brooke \& Kaiser (1970) & II B & II A & I $\beta$ \\
Yellin \& Guth (1970) & A, $\alpha$ & C, $\alpha \beta$ & intermediate \\
Ashmore \& Doerr (1971) & white & red & ST intermediate \\
Barnard et al. (1971) & FT white & FT red & ST oxidative \\
Peter et al. (1972) & FT glycolytic & FT oxidative- & glycolytic \\
\end{tabular}

varies considerably and is therefore somewhat confusing (Table 8).

Peter et al. classified rat skeletal muscle fibres into 3 categories on the basis of: 1 . contraction time, 2 . oxidative capacity and 3. glycolytic capacity. On this basis, the fibres were termed fast twitch glycolytic, fast twitch oxidative-glycolytic and slow twitch oxidative. In the present investigation, a somewhat similar system was used and we designated the 3 fibres in horse skeletal muscle as slow twitch (ST), fast twitch, high oxidative (FTH) and fast twitch (FT) fibres (Table 1).

The relative percentage of the 3 fibre types differed in the various muscles (Table 7 ), as is also the case in other species. Exceptions are the rat and guinea-pig, in which the soleus muscle is predominantly composed of intermediate fibres (ST) (Edgerton \& Simpson 1969, Barnard et al. 1971). Three fibre types with compositions differing in the various muscles of the horse have been reported by Shubber (1971/72) and Gunn (1973). In the present investigation, trained horses (2-8-year olds) were found to have about $76 \%$ FT plus FTH fibres and $24 \%$ ST fibres in the deep part of the gluteus medius muscle. The horse also has $77 \%$ high oxidative fibres (ST plus FTH), which means that 
horse skeletal muscle is designed for both rapid speed of contraction and great endurance, as called for in trotting, for example.

The staining intensity of NADH-diaphorase reflects the fibre's oxidative capacity (Barnard et al. 1970). Due to the fact that the number and size of mitochondria increase with training, the staining intensity of NADH-diaphorase also increases with training (Holloszy 1967, Gollnick et al. 1973).

In the present study, ST fibres were darkest when stained for NADH-diaphorase and, thus, ST fibres in the horse appear to possess the highest oxidative capacity. In other species, either the ST or FTH fibres possess the highest oxidative capacity (Ashmore \& Doerr 1971). In horses it was found that the percentage of FTH fibres increased with age. This is probably the result of more intensive training in older horses as compared to younger horses, since it has been shown that rats, guinea-pigs and monkeys (Galago senegalensis) possess a greater proportion of FTH fibres at the expense of FT fibres after endurance training (Barnard et al. 1970, Baldwin et al. 1972, Edgerton et al. 1972 ). This suggests that it is possible to obtain greater oxidative capacity in the muscle of horses after endurance training.

The increase found in the percentage of FTH fibres with training is thus probably due to an increased oxidative capacity, estimated on the basis of NADH-diaphorase staining intensity. Since some FTH fibres may have had a low oxidative capacity before training, thereby being classified as FT, the increased percentage of FTH fibres must be due to an enhanced oxidative capacity for these fibres (Baldwin et al.).

Fibresize $\left(\mu \mathrm{m}^{2}\right)$ increased with training for all 3 fibre types (Table 4, Fig. 2), but FT produced the greatest increase (25\%). It has been shown in both rat (Armstrong et al. 1973) and horse (Lindholm et al. 1974) that FT fibres are mainly utilized during maximal exertion. Since the horse is regularly trained at maximal or near-maximal exercise levels, it is obvious that the training effect in maximal training mainly involves FT fibres. The relative percentage of fibres and the percentage of total cross-sectional area are not the same. In the present investigation, the percentage of ST fibres amounted to $24 \%$ for all horses, but the total cross-sectional area only amounted to $16.7 \%$ in the untrained horses $(1 / 2-2$ years $)$ and $14.6 \%$ in the trained (2-8-year olds) group of horses (Fig. 2). FTH fibres 
comprised $51 \%$ of the total fibre number for all horses, but only $39.6 \%$ of the cross-sectional area in the untrained horses and $42.6 \%$ in the trained horses constituted FTH area. The FT fibres comprised $25 \%$ of the total fibre number, but $43.7 \%$ of the total cross-sectional area in the untrained horses and $42.8 \%$ in the trained horses comprised FT area. Thus, the total cross-sectional area of FTH fibres increased by $3 \%$, whereas FT and ST area decreased by 0.9 and $2.1 \%$, respectively (Fig. 2).

Horse skeletal muscle is rich in $\mathrm{glycoge} \mathrm{n}$, as illustrated by the intensity of PAS glycogen staining. This staining was more intense in all horse muscle fibres than the PAS glycogen staining of muscle fibres from most other species. In the 3-4-year old horses $100 \%$ of the FT fibres were rated as dark, $78 \%$ of the FTH fibres were rated as dark and $22 \%$ as moderate; $25 \%$ of the ST fibres were dark, $71 \%$ were moderate and $4 \%$ were light. Armstrong et al. rated the staining of almost $100 \%$ of rat $\mathrm{FG}$ (FT) fibres as dark, FOG (FTH) fibres were rated as $1 \%$ dark, $44 \%$ moderate and $55 \%$ light, while SO (ST) fibres were only $25 \%$ moderate, $72 \%$ light and $3 \%$ negative. Thus, the glycogen content of the different fibre types in different species varies considerably. In the present study, the glycogen content increased significantly with age and training (Table 6). In human athletes glycogen content is believed to increase after training (Gollnick et al. 1973, Piehl et al. 1974). The glycogen values for horse skeletal muscle were greater than those described for most other species (Peter et al., Armstrong et al.). However, p y $\mathrm{r} u \mathrm{v}$ a $\mathrm{t}$ and lactate concentrations were very high in the $1 / 2$-year old horses but then declined sharply with age and training. There is no apparent explanation for this phenomenon.

A T P, C P, glucose and G-6-P concentrations did not change significantly with age and training. Nor did $t$ o $t$ a $l$ $\mathrm{muscl}$ e w a $\mathrm{t}$ e $\mathrm{r}$ change with age and training. This is in agreement with studies by Procter \& Best (1932), who found that a period of training failed to produce any significant change in the water content of dog muscles.

An increase in S D H a c t i vity, indicating increased oxidative capacity after training, has been noted in humans (Gollnick et al. 1973, Eriksson et al. 1973) and in rats (Holloszy 1970). In the present study, the increase in SDH activity observed in horses with age may therefore also be assumed to be an effect of training. 
PF K a c t ivit $y$ is indicative of glycolytic activity. In the horse, glycolytic activity increased with training but declined after 4 years of age. An increased PFK activity has also been demonstrated in humans as an effect of training by Gollnick et al. (1973) and Eriksson et al. and in the rat by Baldwin et al. 1973. A difference was observed in SDH and PFK activity in different horse muscles. The low level of SDH activity in the vastus lateralis appears to be correlated with a low percentage of FTH fibres (Table 4).

Data from the present investigation indicate that the composition of horse skeletal muscle is similar in many respects to skeletal muscle composition of various species, as described in previous reports. Since the physiological, biochemical and histochemical response to exercise appeared to change, parameters such as fibre composition, glycogen content, lactate levels, pyruvate levels and enzyme activity (SDH, PFK) must have been changed by age and/or training. The present study is to be used as the basis for further investigation into the physiological and biochemical response of the trotting race-horse to different types of training. Since some horse skeletal muscle disorders are thought to be caused by metabolic changes, data in the present study may be useful for a better understanding of certain muscular diseases in horses.

\section{REFERENCES}

Armstrong, R. B., R. E. Shepherd \& P. D. Gollnick: Glycogen depletion patterns in rat skeletal muscle at different exercise intensities. Pflügers Arch. ges. Physiol. 1973, 344, 1-12.

Ashmore, C. R. \& L. Doerr: Comparative aspects of muscle fiber types in different species. Exp. Neurol. 1971, 31, 408-418.

Baldwin, K. M., G. H. Klinkerfuss, R. L. Terjung, P. A. Molé \& J. O. Holloszy: Respiratory capacity of white, red, and intermediate muscle: adaptive response to exercise. Amer. J. Physiol. 1972, $222,373-378$.

Baldwin, K. M., W. W. Winder, R. L. Terjung \& J. O. Holloszy: Glycolytic enzymes in different types of skeletal muscle: Adaptation to exercise. Amer. J. Physiol. 1973, 225,, 962-966.

Barnard, R. J., V. R. Edgerton \& J. B. Peter: Effect of exercise on skeletal muscle. I. Biochemical and histochemical properties. J. appl. Physiol. 1970, 28, 762-766.

Barnard, R. J., V. R. Edgerton, T. Furukawa \& J. B. Peter: Histochemical, biochemical, and contractile properties of red, white, and intermediate fibers. Amer. J. Physiol. 1971, 220, 410-414. 
Bergström, J.: Muscle electrolytes in man. Scand. J. clin. Lab. Invest. 1962, Suppl. 68.

Bonnier, G. \& O. Tedin: Biologisk variansanalys. (Biological analyses of variance). 2nd rev. Ed. Svenska Bokförlaget, Stockholm 1957.

Brooke, M. H. \& K. K. Kaiser: Muscle fiber types: How many and what kind? Arch. Neurol. (Chic.) 1970, 23, 369-379.

Carlström, B.: Uber die Ätiologie und Pathogenese der Kreuzlähme des Pferdes (Haemoglobinaemia paralytica). (The etiology and pathogenesis in horses with haemoglobinaemia paralytica). Skand. Arch. Physiol. 1932, 63, 164-212.

Close, R. I.: Dynamic properties of mammalian skeletal muscle. Physiol. Rev. 1972, 52, 129-197.

Cooperstein, S. J., A. Lazarov \& N. J. Kurfess: A microspectrophotometric method for the determination of succinic dehydrogenase. J. biol. Chem. 1950, 186, 129-139.

Edgerton, V.R. \& D. R. Simpson: The intermediate muscle fiber of rats and guinea pigs. J. Histochem. Cytochem. 1969, 17, 828837.

Edgerton, V. R., R. J. Barnard, J. B. Peter, C. A. Gillespie \& D. R. Simpson: Overloaded skeletal muscles of a nonhuman primate (Galago senegalensis). Exp. Neurol. 1972, 37, 322-339.

Engel, W. K.: Selective and nonselective susceptibility of muscle fiber types. Arch. Neurol. (Chic.) 1970, 22, 97-117.

Eriksson, B. O., P. D. Gollnick \& B. Saltin: Muscle metabolism and enzyme activities after training in boys $11-13$ years old. Acta physiol. scand. 1973, 87, 485-497.

Gollnick, P. D., R. B. Armstrong, C. W. Saubert IV, K. Piehl \& B. Saltin: Enzyme activity and fiber composition in skeletal muscle of untrained and trained men. J. appl. Physiol. 1972 a, 33, 312_319.

Gollnick, P. D., K. Piehl, C. W. Saubert IV, R. B. Armstrong \& B. Saltin: Diet, exercise, and glycogen changes in human muscle fibers. J. appl. Physiol. 1972 b, 33, 421-425.

Gollnick, P. D., R. B. Armstrong, B. Saltin, C. W. Saubert IV, W. L. Sembrowich \& $R$. E. Shepherd: Effect of training on enzyme activity and fiber composition of human skeletal muscle. J. appl. Physiol. 1973, 34, 107-111.

Gunn, H. M.: Further observations on laryngeal skeletal muscles in the horse. Equine vet. J. 1973, 5, 77-80.

Henneman, E. \& C. B. Olson: Relations between structure and function in the design of skeletal muscle. J. Neurophysiol. 1965, 28, 581 -598 .

Holloszy, J. O.: Biochemical adaptations in muscle. Effects of exercise on mitochondrial uptake and respiratory enzyme activity in skeletal muscle. J. biol. Chem. 1967, 242, 2278—2282. 
Holloszy, J. O., L. B. Oscai, I. L. Don \& P. A. Molé: Mitochondrial citric acid cycle and related enzymes: Adaptive response to exercise. Biochem. biophys. Res. Commun. 1970, 40, 1368-1373.

Jacobs, S.: The determination of nitrogen in biological material. Meth. biochem. Anal. 1965, 13, 241-263.

Karlsson, J.: Lactate and phosphagen concentrations in working muscle of man. Acta physiol. scand. 1971, Suppl. 358.

Karlsson, J., B. Diamant \& B. Saltin: Muscle metabolites during submaximal and maximal exercise in man. Scand. J. clin. Lab. Invest. $1970,26,385-394$.

Kugelberg, E. \& L. Edström: Differential histochemical effects of muscle contractions on phosphorylase and glycogen in various types of fibres: relation to fatigue. J. Neurol. Neurosurg. Psychiat. 1968, 31, 415-423.

Lindholm, A.: Metabolic response and muscle metabolites during different exercise intensities in trotting horses. Acta physiol. scand. 1973, Suppl. 396.

Lindholm, A., H. Bjerneld \& B. Saltin: Glycogen depletion pattern in muscle fibres of trotting horses. Acta physiol. scand. 1974, 90, 475-484.

McArdle, B.: Myopathy due to a defect in muscle glycogen breakdown. Clin. Sci. 1951, 10, 13-35.

Müller, R. \& E. Kugelberg: Myopathy in Cushings syndrome. J. Neurol. Neurosurg. Psychiat. 1959, 22, 314-319.

Munro, H. N.\& A. Fleck: The determination of nucleic acids. Meth. biochem. Anal. 1966, 14, 113-176.

Novikoff, A. B., W. Shin \& J. Drucker: Mitochondrial localisation of oxidative enzymes: staining results with two tetrazolium salts. J. biophys. biochem. Cytol. 1961, 9, 47-61.

Padykula, H. A. \& E. Herman: The specificity of the histochemical method of adenosine triphosphatase. J. Histochem. Cytochem. $1955,3,170-195$.

Padykula, H. A. \& G. F. Gauthier: Morphological and cytochemical characteristics of fiber types in normal mammalian skeletal muscle. In Exploratory Concepts in Muscular Dystrophy and Related Disorders. A. T. Milhorat, ed., Excerpta med. Found. (Amst.) Sect. 1967, 117-128.

Pearse, A. G. E.: Histochemistry - Theoretical and Applied. Appendix 9, Little Brown, Boston 1961, 832.

Peter, J. B., R. J. Barnard, V. R. Edgerton, C. A. Gillespie \& R. E. Stempel: Metabolic profiles of three fiber types of skeletal muscle in guinea pigs and rabbits. Biochemistry 1972, 11, 2627-2633.

Piehl, $K$., S. Adolfsson \& K. Nazar: Glycogen storage and glycogen synthetase activity in trained and untrained muscle of man. Acta physiol. scand. 1974. In press.

Procter, H. A.\& C. H. Best: Changes in muscle glycogen accompanying physical training. Amer. J. Physiol. 1932, 100, 506—510. 
Romanul, F. C. A.: Enzymes in muscle. I. Histochemical studies of enzymes in individual muscle fibers. Arch. Neurol. (Chic.) 1964, $11,355-369$.

Shonk, C. E. \& G. E. Boxer: Enzyme patterns in human tissue. I. Methods for the determination of glycolytic enzymes. Cancer Res. 1964, 24, 709-724.

Shubber, A. H.: On the succinic dehydrogenase activity in equine skeletal muscle fibers. Acta morph. neerl.-scand. 1971/72, 9, 229-234.

Snedecor, G. W. \& W. G. Cochran: Statistical Methods. 6th Ed. The Iowa State University Press, Ames, Iowa, USA 1967.

Stein, J.M.\& H. A. Padykula: Histochemical classification of individual skeletal muscle fibers of the rat. Amer. J. Anat. 1962, 110, 103124.

Yellin, H. \& L. Guth: The histochemical classification of muscle fibers. Exp. Neurol. 1970, 26, 424-432.

\section{SAMMANFATTNING}

Fibersammansättning, enzymaktivitet och koncentrationen av metaboliter och elektrolyter i muskulaturen hos travhästar.

Muskelbiopsier från gluteus medius, vastus lateralis, triceps brachii och infraspinatus har tagits på 68 travhästar i åldern $1 / 2-8$ år. Muskelbitarna har undersökts på innehåll av glykogen, olika metaboliter, elektrolyter, vatten, RNA, protein, enzymaktivitet (SDH och PFK) samt fibersammansättning. Muskelfibrerna klassificerades i tre huvudgrupper: Långsamma (ST), snabba-högoxidativa (FTH) och snabba-lågoxidativa (FT) fibrer.

Antalet FTH fibrer ökade med ålder och var i medeltal $54 \%$ vid 4-8 års ålder. ST fibrerna utgjorde $24 \%$ vilket ej ändrade sig med ålder. Ytorna av de enskilda fibrerna var större hos hästar äldre än 2 år i jämförelse med yngre hästar. ökningen uppgick till $25 \%$ för FT fibrer och till $15 \%$ för ST och FTH fibrer. Fiberytan av FT omfattade den största delen av totala tvärsnittsytan (43\%).

Glykogenkoncentration i vila var 95 mmoler glukosenheter $\times \mathrm{kg}^{-1}$ våt muskel hos föl ( $1 / 2$ år) och ökade med ålder samt var hos 5-8 år gamla hästar 126 mmoler $\times \mathrm{kg}^{-1}$. Laktat- och pyruvatvärden på föl var i genomsnitt 5,5 respektive $0,49 \mathrm{mmoler} \times \mathrm{kg}^{-1}$ våt muskel. Vid 8 års ålder hade dessa värden sjunkit till 2,9 respektive 0,03 mmoler $\times \mathrm{kg}^{-1}$. Övriga undersökta metaboliter (ATP, CP, G-6-P, glukos) ändrades inte med hästens ålder.

Vatteninnehållet i muskulaturen var i genomsnitt $75 \%$ hos samtliga hästar. Koncentrationen av $\mathrm{Na}^{+}$var högre och av $\mathrm{K}^{+}$lägre $\mathrm{i}$ den äldsta gruppen hästar jämfört med föl. $\mathrm{Mg}^{2+}$-koncentrationen ändrades inte med ålder. Aktiviteten av SDH var hos föl $6,1 \mu$ moler $\times(\mathrm{g}$ $\times$ min $)^{-1}$, steg hos äldre hästar och nådde $13,6 \mu$ moler $\times(\mathrm{g} \times \min )^{-1}$ hos 8 år gamla hästar. Aktiviteten av PFK steg till 4 års ålder varefter 
den åter minskade. Koncentrationen av RNA och protein ändrades inte med ålder. Inga signifikanta skillnader beträffande de undersökta parametrarna noterades i de fyra olika muskler som undersökts.

Mot bakgrunden av erhållna resultat konkluderas att undersökningar baserade på muskelbiopsier bör vara av värde vid diagnostisering av muskelsjukdomar hos häst och vid utvärdering av olika behandlingsformer. Av speciellt värde kan sådan undersökning visa sig vara i samband med framtagande av mer ändamålsenliga träningsmetoder för sporthästar.

(Received January 7, 1974).

Reprints may be requested from: Arne Lindholm, Department of Clinical Biochemistry, Royal Veterinary College, Fack S-104 05 Stockholm 50, Sweden. 